\title{
Antibacterial effect of fucoidan from Sargassum wightii against the chosen human bacterial pathogens
}

\author{
*Thangapandi Marudhupandi, Thipparamalai Thangappan Ajith Kumar \\ Centre of Advanced Study in Marine Biology, Faculty of Marine Sciences, Annamalai University, Parangipettai - 608 502, India
}

\begin{abstract}
The present study was aimed to evaluate the antibacterial capability of fucoidan from Sargassum wightii against the chosen human bacterial pathogens. The major chemical constituents of the extracted fucoidan were analyzed by biochemical methods. It showed that the extracted fucoidan contains $52.86 \pm 0.64 \%$ of fucose and $29.26 \pm 0.83 \%$ of sulphate. The antibacterial efficacy was performed by agar well diffusion, minimum inhibitory concentration (MIC) and minimum inhibitory concentration (MBC) method. The maximum antibacterial activity $18.6 \pm 0.32 \mathrm{~mm}$ was obtained for Vibrio cholera and the minimum activity $8.6 \pm 0.26 \mathrm{~mm}$ was obtained for Salmonella typhi. Result of this manifested the considerable antibacterial potentiality of fucoidan against human bacterial pathogens. Toxicity of fucoidan was evaluated by brine shrimp toxicity assay. No toxic effect was observed in fucoidan. Our study concluded that fucoidan might be used as natural and safe antibiotics in curing many bacterial diseases. Further study is required to get the better understanding of mode of action of fucoidan against the bacterial pathogens.
\end{abstract}

Key Words: Seaweed, polysaccharides, fucose, sulphate, antibacterial activity, brine shrimp toxicity.

\section{INTRODUCTION}

Infectious diseases are a major cause of morbidity and mortality worldwide (WHO, 2004). Pharmaceutical industries are interested in marine plants because of their rich and active molecules (Perez, 1997; Madhusudan et al., 2011). Certainly, the therapeutic potential of certain active molecules is extremely promising, notably for an antimicrobial and antiviral use (Val et al., 2001; Nakajima et al., 2009). Microorganisms have developed adaptation mechanisms against the action of antimicrobial drugs (AlHaj et al., 2009). This is a major concern and an urgent need for searching for new and safe antibacterial agents. Several studies have been investigated about the biological activities of algae extracts (Tringali, 1997). Different active molecules from seaweeds showed the antimicrobial activities against the pathogens e.g., $S$. aureus or $P$. aeruginosa that commonly cause infection in the human (Selvin and Lipton, 2004). This is intended the researcher to continued their research into searching of novel molecules from marine algae. Fucoidan a sulphated polysaccharides, isolated from different seaweed species have been extensively studied due to their varied biological activities like pharmacological activity i.e., antithrombotic, anti-inflammatory, blood lipids reducing effect, antioxidant, and anticomplementary properties, activity against hepatopathy, uropathy and renalpathy, gastric protective effects and therapeutic potential in surgery (Li et al., 2008). Although manifold studies on the biological activities of fucoidans have been performed but an antibacterial effect of fucoidan has been poorly reported. In this background the present study was conducted to evaluate the antibacterial capability of fucoidan from Sargassum wightii against eight human bacterial pathogens.

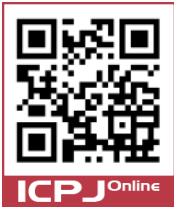

\section{MATERIALS AND METHODS}

\section{Isolation of fucoidan}

The brown seaweed Sargassum wightii was collected from the Mandapam coast of Tamilnadu, India and it was identified by the seaweed expert Dr. M. Ganesan, CSMCRI, Mandapam. Then the collected seaweeds were washed well enough and dried at room temperature in shadow, pulverized in a blender and sieved. The extraction of fucoidan was performed as described by Yang et al. (2008). Milled seaweed of about $20 \mathrm{~g}$ was treated with a liter of ethanol and stirred with a mechanical stirrer for about 12 hours at room temperature in order to remove proteins and pigments. After washing with acetone, centrifugation is done at $1800 \times \mathrm{g}$ for $10 \mathrm{~min}$. Then the residue was left to dry at room temperature. After well drying a biomass, $5 \mathrm{~g}$ was taken and extracted in $100 \mathrm{ml}$ of distilled water at $65^{\circ} \mathrm{C}$ with stirring for an hour. The extraction was done twice and the extracts were pooled. The combined extracts were centrifuged at $18500 \times \mathrm{g}$ for 10 minutes and the supernatant was collected. Then the supernatant was mixed well with $1 \% \mathrm{CaCl}_{2}$ and the solution was kept at $4^{\circ} \mathrm{C}$ for overnight to precipitate Alginic acid. The solution was then centrifuged at $18500 \times \mathrm{g}$ for 10 minutes and the supernatant was collected. Ethanol (99\%) was added into the supernatant in order to arrive upon the final ethanol concentration of $30 \%$ and the solution was placed at $4^{\circ} \mathrm{C}$ for 4 hours. Again the solution was centrifuged at $18500 \times \mathrm{g}$ for 10 minutes and the supernatant was collected. Again ethanol (99\%) was added into the supernatant in order to arrive upon the final ethanol concentration of $70 \%$ and the solution was placed at $4^{\circ} \mathrm{C}$ for overnight. The intact fucoidan was then obtained through filtration of the solution with a nylon membrane $0.45 \mu \mathrm{m}$ size. Fucoidan yield was estimated based on the dried biomass obtained after the treatment of the milled sample with $85 \% \mathrm{EtOH}$ as a percentage of the algal dry weight (\% dry weight).

\section{Chemical analysis}

Fucose was estimated by the phenol-sulphuric acid method by Dubois et al., (1956) using L-fucose as stand- 
ard. Sulfate content was determined according to the gelatin-barium method by Saito et al., (1990) using sodium sulfate as standard.

\section{Antibacterial assays \\ Bacterial culture}

In this study, the clinical pathogens such as Escherichia coli, Klebsiella pneumoniae, Vibrio cholerae, Proteus proteus, Shigella sonnie, Pseudomonas aeruginosa, Salmonella typhi and Klebsiella sp., were obtained from the Rajah Muthiah Medical College, Annamalai University, Tamil Nadu, India. Collection were reconstituted in Muller-Hinton's broth, cultures were resuscitated under aerobic conditions at $37^{\circ} \mathrm{C}$ and $200 \mathrm{rpm}$ to reach exponential growth. The concentration $\left(10^{7}\right.$ colony-forming units $\left.(\mathrm{CFU}) / \mathrm{ml}\right)$ was routinely estimated by spectrophotometric turbidity measurement at $600 \mathrm{~nm}$ on a spectrophotometer and by CFU counts on tryptic soy agar (TSA).

\section{Screening of antibacterial activity}

The antibacterial activity of fucoidan was performed by agar plate diffusion assay. Petri plates containing MullerHinton's agar medium was prepared in sterilized water. Then $0.1 \mathrm{ml}$ of test organisms were taken from the stock broth and swabbed on agar medium by using sterilized buds. Then the wells $6 \mathrm{~mm}$ made on the agar plates by using sterilized well cutter. Fucoidan $500 \mu \mathrm{g} / \mathrm{ml}$ fucoidan was prepared; $500 \mu \mathrm{g} / \mathrm{ml}$ of tetracycline was used as a positive control. Then it was added to the respective wells by using sterilized pipette. Then the plates were incubated at $37^{\circ} \mathrm{C}$ for $24 \mathrm{~h}$. The antibacterial activity of the test fucoidan was observed through zone of inhibition (in $\mathrm{mm}$ ) on the plates.

\section{Determination of Minimum Inhibitory Concentrations}

The minimum inhibitory concentration (MIC) was tested in the listed strains. Equal volumes of each bacterial strain culture, were applied to Muller-Hinton's broth (MHB) with different concentration of fucoidan in the test tubes ranging from 250, 125, 62.5, 31.25, 15.62, 7.81, 3.90, 1.95 and $0.97 \mu \mathrm{g} / \mathrm{ml}$, respectively. Whereas, the control used for the study was prepared without fucoidan. These serially diluted cultures were then incubated at $37^{\circ} \mathrm{C}$ for $24 \mathrm{~h}$. After the incubation period, turbidity was observed. MIC was defined as the lowest concentration of fucoidan that completely inhibited the visible growth of the test microorganisms.

\section{Minimum bactericidal concentration}

To determine minimum bactericidal concentration (MBC), aliquots of one loopful of the above serially diluted and incubated concentration were streaked individually on petridish containing Muller Hinton's agar and incubated at $37^{\circ} \mathrm{C}$ for $18 \mathrm{~h}$, the lowest concentration of fucoidan in the plate that shows no bacterial growth on agar plate represents the $\mathrm{MBC}$ value for fucoidan.

\section{Brine shrimp toxicity assay}

A brine shrimp (Artemia) bioassay was performed to assess the toxicity of the fucoidan. Brine shrimp (Artemia salina) eggs were hatched for $48 \mathrm{~h}$ in a conical flask containing $500 \mathrm{ml}$ of filtered seawater. The flask was well aerated with the aid of an air pump and incubated at $27 \pm 1^{\circ} \mathrm{C}$ with constant illumination (2000 lux approx.) for $48 \mathrm{~h}$. After hatching, the active nauplii were collected for this assay. The fucoidan was dissolved in $1 \mathrm{ml}$ of aerated seawater at various concentrations $(10,50,250,500$ and $1000 \mu \mathrm{g} / \mathrm{ml})$. An aliquot of each concentration $(1 \mathrm{ml})$ was
Table 1: Screening of anti-bacterial activity of fucoidan against human bacterial pathogens.

\begin{tabular}{lcccc}
\hline \multicolumn{1}{c}{ Bacteria } & $\begin{array}{c}\text { Fucoidan } \\
\mathbf{( 5 0 0} \boldsymbol{\mu g} / \mathbf{m l})\end{array}$ & $\begin{array}{c}\text { Positive control } \\
\mathbf{( 5 0 0} \boldsymbol{\mu g} / \mathbf{m l})\end{array}$ & MIC & MBC \\
\hline Escherichia coli & $11.03 \pm 0.3$ & $24 \pm 0.2$ & 125 & 250 \\
Klebsiella pneumonia & $9.6 \pm 0.17$ & $19 \pm 0.21$ & 250 & 500 \\
Vibrio cholera & $18.6 \pm 0.32$ & $22 \pm 0.36$ & 31.25 & 62.5 \\
Proteus proteus & $13.2 \pm 0.24$ & $26 \pm 0.21$ & 125 & 250 \\
Shigella sonnie & $14.83 \pm 0.15$ & $20 \pm 0.28$ & 125 & 250 \\
Pseudomonas aeruginosa & $16.23 \pm 0.37$ & $20 \pm 0.13$ & 62.5 & 150 \\
Salmonella typhi & $8.6 \pm 0.26$ & $21 \pm 0.32$ & 250 & 500 \\
Klebsiella sp. & $14.3 \pm 0.41$ & $27 \pm 0.28$ & 125 & 250 \\
\hline
\end{tabular}

transferred, into the aerated seawater $(9 \mathrm{ml})$. Ten nauplii were transferred to each tube. The control group was treated identically without the addition of fucoidan to the $10 \mathrm{ml}$ of seawater. After $24 \mathrm{~h}$ the number of survivors was counted and the fatality was calculated in percentage. The lethal concentration of fucoidan was defined as that which caused $50 \%$ mortality of the nauplii ( $\mathrm{LC}_{50}$ ). Tests were carried out in triplicate.

\section{RESULTS AND DISCUSSION}

Species of brown seaweed are well known to contain large amounts of cell-wall polysaccharide, fucoidan, which is not found in terrestrial plants (Asker et al., 2007). Fucoidan has a substantial component of L-fucose and sulfate ester groups (Bilan et al., 2006) and has a wide range of pharmacological and biomedicinal properties (Guven et al., 1999). Similarly, Berteau and Mulloy (2003) reported that the antimicrobial activity of the polysaccharides is related its chemical structure and ester sulfate groups. On the other hand, several species of brown seaweed that has a high sulfate content have been reported to show differences in antimicrobial activities (Adhikari et al., 2006; Asker et al., 2007). In the present study, fucoidan was extracted from brown seaweed Sargassum wightii by the method proposed by Yang et al. (2008) using ethanol and the yield of fucoidan was observed at $4.24 \pm 0.35 \%$. The major chemical constituent of the fucoidan was observed. The extracted fucoidan contains $52.86 \pm 0.64 \%$ of fucose and $29.26 \pm 0.83 \%$ of sulphate. In the present investigation, the yield was close to the value of $6.2 \%$, reported by Chattopadhyay et al., 2010 in brown seaweed Turbinaria conoids and also yield value of $1.1-4.8 \%$ of fucoidan was observed in some other brown seaweed (Bilan et al., 2006). The chemical constituent of fucoidan from Sargassum wightii had analogous amounts of fucose $(42-66 \%)$ with smaller amounts of sulphate (11.5-34.2\%) in combination with other seaweeds (Nakajima et al., 2009; Rioux et al., 2007).

For the present study, antibacterial effect of fucoidan was performed against the human bacterial pathogens by agar well diffusion method. The result was displayed in Table 1 . The maximum activity $18.6 \pm 0.32 \mathrm{~mm}$ was obtained for Vibrio cholera and the minimum activity $8.6 \pm$ $0.26 \mathrm{~mm}$ was obtained for Salmonella typhi. The minimum inhibitory concentration and minimum bactericidal concentration of fucoidan was displayed in Table 1. The order of sensitivity to MIC and MBC of fucoidan was found between the 31.25 to $250 \mu \mathrm{g} / \mathrm{ml}$ and 62.5 to $500 \mu \mathrm{g}$ $/ \mathrm{ml}$ to the respective pathogens. In the present study, considerable activity was observed to the bacterial pathogens as mentioned in Table 1. Similarly, Chotigeat et al., 2004 reported that the crude fucoidan from Sargassum polycystum showed the activity at $12 \mathrm{mg} / \mathrm{ml}$ against the 
Staphylococcus aureus (10mm). Similarly, Pierre et al., (2011) also reported the antimicrobial effect sulfated galactan from Chaetomorpha aerea against the human bacterial pathogens such as Staphylococcus aureus, Salmonella enteretidis, P. aeruginosa, Enterococcus faecalis, Bacillus subtilis, Micrococcus luteus and Candida glabnata. It was suggested that the molecular mechanism of fucoidan on antibacterial activity is required to be further studied. However, this indicates that fucoidan possessed the inhibitory and bactericidal effect against the above mentioned human bacterial pathogens.

Nowadays, the brine shrimp assay is considered as an excellent method for preliminary investigations of toxicity, to several bioactive molecules from various sources (Quignard et al., 2003). Interestingly, Parra et al., (2001) reported that, the toxic effect of medicinal plants was positively correlated between the lethality to brine shrimp and the corresponding oral lethal dose in mice. Our results have revealed that fucoidan from Sargassum wightii had nontoxic effect against the brine shrimp (Artemia). In the brine shrimp toxicity test, no mortality was observed during the incubation period at various concentrations of fucoidan.

\section{ACKNOWLEDGEMENT}

The authors are grateful to the authorities of CAS in Marine Biology, Faculty of Marine Sciences and to Annamalai University for providing the necessary facilities. The first author extended his sincere thanks to the University Grant Commission, New Delhi, India for its financial assistance under the scheme of CPEPA.

\section{REFERENCES}

Adhikari, U.C.G., Mateu, K., Chattopadhyay, C.A., Pujol, E.B., Damonte., \& Ray, B., et al. 2006. Structure and antiviral activity of sulfated fucan from Stoechospermum marginatum. Phytochemistry, 67, 2474-2482. [DOI]

Al-Haj, N.A., Mashan, N.I., Shamsudin, M.N., Mohamad, H., Vairappan, C.S., \& Sekawi, Z., et al. (2009). Antibacterial activity in marine algae Eucheuma denticulatum against Staphylococcus aureus and Streptococcus pyogenes. Research Journal Biological Science 4, 519-524. [Link]

Asker, M.M.S., Mohamed, S.F., Ali, F.M., \& Sayed, O.H.E., et al. (2007) Chemical structure and antiviral activity of water-soluble sulfated polysaccharides from Sargassum latifolium. Journal of Applied Science Research, 3, 1178-1185. [Link]

Berteau, O., \& Mulloy, B., (2003). Sulfated fucans, fresh perspectives: structures, functions, and biological properties of sulfated fucans and an overview of enzymes active toward this class of polysaccharide. Glycobiology, 13, 29R-40R. [DOI]

Bilan, M.I., Grachev, A.A., Shashkov, A.S., Nifantiev, N.E., \& Usov, A.I., et al. (2006). Structure of a fucoidan from the brown seaweed Fucus serratus L. Carbohydrate Research, 341(2), 238-245. [DOI]

Chattopadhyay, N., Ghosh, T., Sinha, S., Chattopadhyay, K., Karmakar, P. \& Ray, B., et al. (2010). Polysaccharides from Turbinaria conoides: Structural features and antioxidant capacity. Food Chemistry, 118, 823829. [DOI]
Chotigeat, W., Tongsupa, S., Supamataya, K., \& Phongdara, A., et al. (2004). Effect of fucoidan on disease resistance of black tiger shrimp. Aquaculture, 233, 23-30. [DOI]

Dubious, M., Gilles, K.A., Hamilton, J.K., Rebers, P.A., \& Smith, F., et al. (1956). Colorimetric method for determination of sugars and related substances. Analytical Chemistry, 28(3), 350-366. [DOI]

Guven, K.C.B., Guvener \& Guler, E., et al. (1999). Pharmacological activities of marine algae. In I. Akatsuka (ed.). Introduction to Applied Phycology, SPB Academic Publishing by The Hague, Netherlands. pp67-92.

Li, B., Lu, F., Wei. X., \& Zhao, R., et al. (2008). Fucoidan: Structure and Bioactivity. Molecule, 13, 1671-1695. Doi: 10.3390/molecules13081671.

Madhusudan, C., Manoj, S., Rahul, K., \& Rishi, C.M., et al. (2011). Seaweeds: A diet with nutritional, medicinal and industrial value. Research Journal Medicinal Plant, 5,153-157. [DOI]

Nakajima, K., Yokoyama, A., \& Nakajima, Y., et al. (2009). Anticancer effects of a tertiary sulfonium compound, dimethylsulfoniopropionate, in green sea algae on Ehrlich ascites carcinoma-bearing mice. Journal of Nutritional Science and Vitaminology, 55, 434-438. [DOI]

Parra, A.L., Yhebra, R.S., Sardinas, I.G., \& Buela, L.I., et al. (2001). Comparative study of the assay of Artemia salina L. and the estimate of the medium lethal dose (LD50 value) in mice, to determine oral acute toxicity of plant extracts. Phytomedicine, 8, 395-400. [DOI]

Perez, R. (1997). Ces algues qui nous entourent: conception actuelle, role dans la biosphere, utilisations, culture. In: IFREMER (eds.). Editions Broche, Plouzane, France. pp. 65-178.

Pierre, G., Sopena, V., Juin, C., Mastouri, A., Graber, M., \& Maugard, T., et al. (2011). Antibacterial Activity of a Sulfated Galactan Extracted from the Marine Alga Chaetomorpha aerea Against Staphylococcus aureus. Biotechnology and Bioprocess Engineering, 16, 937-945. [DOI]

Quignard, E.L., Pohlit, A.M., Nunomura, S.M., Pinto, A.C., Santos, E.V., Morais, S.K., Alecrim, A.M., Pedroso, A.C., Cyrino, B.R., Melo, C.S. Finney, E.K., Gomes, E.O., Souza, K.S., Oliveira, L.C., Don, L.C., Silva, L.F., Queiroz, M.M., Henrique, M.C., Santos, M., Pinto, P.S., \& Silva, S.G., et al. (2003). Screening of plants found in Amazonas state for lethality towards brine shrimp. Acta Amazonica, 33, 93-104. [DOI]

Rioux, L.E., Turgeon, S.L., Beaulieu, M., (2007). Characterization of polysaccharides extracted from brown seaweeds. Carbohydrate Polymer, 69(3), 530-537. [DOI]

Saito, K., Nishijima, M., \& Miyazaki., et al. (1990). Further Examination on the Structure of an Alkali-Soluble Glucan Isolated from Omphalia lapidescens: Studies on Fungal Polysaccharide. Chemical and Pharmaceutical Bulletin, 38 (6), 1745-1747. [DOI]

Selvin, J., \& Lipton, A.P., (2004). Biopotentials of Ulva fasciata and Hypnea musciformis collected from the Peninsular Coast of India. Journal of Marine Science and Technology, 12, 1-6. [Link]

Tringali, C. (1997). Bioactive metabolites from marine algae: recent results. Current Organic Chemistry, 1, 375-394.

Val, A.G.D., Platas, G., Basilio, A., Cabello, A., Gorrochategui, J., Suay, I., Vicente, F., Portillo, E., Rio, M.J.D., Reina, G.G., \& Pelaez, F., et al. (2001). Screening of antimicrobial activities in red, green and brown macroalgae from Gran Canaria (Canary Islands, Spain). International Microbiology, 4, 35-40. [DOI]

WHO (2004). The world health report. Changing history. Statistical annex. Death by cause, sex and mortality stratum in WHO regions, estimates for 2002. Geneva, Switzerland WHO; pp. 120-121. [Link]

Yang, C., Chung, D., \& You, S.G., et al. (2008). Determination of physicochemical properties of sulfated fucans from sporophyll of Undaria pinnatifida using light scattering technique. Food Chemistry, 111, 503-507. [DOI] 